\title{
THE QUEST FOR TENURE IN THE UNITED STATES
}

\author{
WIIIIAM R. VANCE
}

It seems a shameful thing to confess that the quest for "tenure" of land in the American States, so busily carried on in modern times, reminds one of the childish game, "Button, button, who has the button?" It certainly appears disrespectful to such an ancient and honorable institution as English land tenure, to associate it with so silly a game. Yet is there not a resemblance? Lands in Colonial America were undoubtedly granted by the English Crown to be held in free and common socage, "as of our Manor at East-Greenwich, in the County of Kent," ${ }^{\prime}$ or, as in the patent given by Charles II to William Penn," "to bee holden of Us Our heires and Successors, Kings of England, as of Our Castle of Windsor in Our County of Berks, in free and comon Socage, by fealty only for all Services, and not in Capite or by Knights Service: Yielding and paying therefore to Us, Our heires and Successors, Two Beaver Skins ...."3 Unquestionably there was land tenure in Colonial lands, even though of the mild and somewhat defeudalized type possible after the statute of I2 Car. II, c. 24. Then what has become of it? Look about as you may, you will see none of the familiar signs of English land tenure; no doing of homage, no swearing of fealty, no reliefs, no rent service or distress in case of grants in fee (except in Pennsylvania), no escheat to the original grantor, even though such grantor be the Federal government, but only to the State in which the land lies. ${ }^{4}$ There appears to be no tenure at all. Then who has the button? What can have become of that Colonial tenure, which was so very real and active as to keep the colonists in unceasing conflict and turmoil with the royal governors, or unhappy proprietaries, who attempted to take advantage of it and enforce the rendering of services reserved, here nearly always taking the form of quit rents, and

\footnotetext{
${ }^{2}$ As in the first charter of Virginia ( 1606$)$. See 7 Thorpe, Constitutions, Charters and Other Organic Laws (1909) 3783, 3789; I Hening, Statutes at Large (1823) 57, 66.

${ }^{7}$ In 168I. See 5 Thorpe, op. cit. supra note I, at pp. 3035, 3037. So in the Maryland charter (1632), 3 ibid. 1669 , I67x.

${ }^{3}$ As to tenure of land embraced within the Louisiana Purchase of 1803 , see the interesting essay by Prof. Manley $O$. Hudson, Land Tenure and Conveyances in Missouri (I9I5) 8 LAw SERIES, Mo. Butr. 3. It seems that lands have always been regarded as allodial in Louisiana. See Xiques v. Bujac (1852) 7 La. Ann. 498, 504 .

'Etheridge v. Doe (1851) I8 Ala. 565; Crane v. Reeder (1870) 21 Mich. 24; I Woerner, American Law of Administration (3d ed. I923) 459. This fact, however, does not negative the feudal origin of modern escheat. The state merely succeeds the Federal Government as chief lord of the fee, just as the state of Texas succeeded the Mexican Government upon its declaration of independence. See Hamilton v. Brown (1895) I6I U. S. 256, 263.
} 
which did so much to bring on the Revolution? The answer has puzzled our scholars and judges. ${ }^{5}$ Professor Gray thought it not probable that so "fundamental an alteration in the theory of property as the abolition of tenure would be worked by a change of political sovereignty,"

It is quite true that some of our states quickly took advantage of their newly acquired independence to abolish all feudal tenures by legislative fiat, declaring that thenceforth all lands should be allodial. ${ }^{7}$ Some others, while seeming to recognize the continuance of tenure, declared that thereafter all land tenure should be allodial, ${ }^{8}$ an expression that greatly pains ${ }^{9}$ some writers to whom the word allodium

\footnotetext{
o "In those States in which, by express legislative enactment, lands have not
} been declared allodial, while tenure exists it is only in theory. ... Though there are some opinions that tenures fell with the Revolution, yet all agree that they existed before, and the better opinion appears to be that they still exist." Sharswood's note, 2 Blackstone, Commentaries (Lewis's ed. 1898) *78. "Though our property is allodial, yet feudal tenures may be said to exist among us in their consequences and the qualities which they originally imparted to estates." Gibson, J., in Lyle v. Richards (1823, Pa.) 9 Serg. \& R. 322, 333. See also Kavanaugh v. Cohoes Power \& Light Corp. (I92I, N. Y.) Ir4 Misc. 590; Wallace v. Harmstad (1863) $44 \mathrm{~Pa} .492$.

- Gray, Rule Against Perpetuities (3d ed. 1915) sec. 22. Professor Kales was of the same opinion. Kales, Estates, Future Interests and Illegal Conditions (1920) 9.

${ }^{2}$ E.g. Connecticut, Act of 1793, (Rev. Sts. I821, tit. 56, ch. I, sec. I); Conn. Gen. Sts. I918, sec. 5080; Virginia Sts. I779, ch. I3; Io Hening, op. cit. supra note I, ch. I3, sec. 6.

'See New Jersey, Act of 1795, (Rev. Laws, I82r, r66); 2 N. J. Comp. Sts. Igro, Conveyances, sec. 9.

- See Gray, op. cit. supra note 6, at p. I7, note I; Fowler, History of Real Property Law of New York (1895) 80. Allodium is almost as uncertain of meaning as in its origin. By the Century Dictionary it is defined as "real estate held in absolute independence, without being subject to any rent, service or acknowledgement to a superior." Despite the statement so frequently met in treatises and judicial opinions (for example, see I Story, Constitution [5th ed. 1891] 125, I26; Wallace v. Harmstad, supra note 5), that allodial ownership is absolute ownership of the soil, it is probable that no subject or citizen in any English-speaking country has ever held his land in "absolute independence." Rather it may be said that "every man holds his estate... . subject not only to the right of eminent domain, but to the right of the government to control the use of it by such rules and limitations as the public good requires.". Washburn, Real Property (4th ed. 1876 ) 65 . The patent fact that the ultimate or absolute ownership of all lands within the state is in the people thereof, or as we say for convenience, in the state, and that the occupant of any parcel of land possesses or "holds" it subject to the liability that the state may exercise certain important powers with respect to it, is recognized in the constitutions and statutes of some of the states. See Ga. Code, IgIr, sec. 3623 , which declares that all realty is held under the state as original owner. See note ro infra; 2 N. J. Comp. Sts. Igro, Conveyances, sec. 14. Art. I, sec. I3, of the Constitution of New York, adopted in 1846 , deciares all lands within the state to be allodial, while sec. II provides that "The people of this State, in their right of sovereignty, are deemed to possess the original and ultimate property in and to all lands within the jurisdiction of the State; and all lands the title to which shall fail, from a defect of heirs, shall 
negatives feud, and therefore tenure. Yet others simply forgot it. ${ }^{10}$ And curiously enough, those which forgot about tenure have since been no more troubled by it than those which solemnly destroyed it. Yet it cannot be said that its absence has not been felt, for some eminent writers $^{11}$ and judges ${ }^{12}$ have declared that the destruction of tenure between grantor and grantee by the statute Quia Emptores renders impossible the existence of such a legal right as the so-called possibility of reverter; and this in spite of the declaration of many judges, English and American, that it does exist, and not a few American decisions to that effect. ${ }^{13}$ Most lawyers are of opinion, however, that, except possibly in Pennsylvania, it makes precious little difference in the practical working of our law whether tenure exists or not. ${ }^{14}$ One may well

revert, or escheat to the people." "Allodial" ownership appears to mean no more than ownership freed from the oppressive duties of service and fealty, with the accompanying liability to distress, owed to some person with superior interests (i. e. a superior lord) in the same land. See Gray, loc. cit. supra note 9. Such being the meaning of the word, the expression "allodial tenure" is proper enough. Certainly the New York courts have emphatically stated that while all feudal tenures between private citizens have been abolished, the seigniory of all lands is in the people of the state. DePeyster v. Michael (1852) 6 N. Y. $467 ; V a n$ Rensselaer v. Demison (1866) 35 N. Y. 393. "Chancellor Kent's objection-that to declare socage lands of the nineteenth century allodial was a change without substance-seems to be not devoid of foundation." Fowler, op. cit. supra, at p. 99 ; see 4 Kent, Commentaries, *2.

${ }^{10}$ Delaware and North Carolina appear never to have legislated on the subject of tenure. An ancient statute of South Carolina, enacted in 17r2, declaring all land tenure to be in free and common socage, appears to have remained unnoticed and unrepealed from that date to the present time. See infra note 89. It was not until I86r that a zealous code commission in Georgia thought it desirable to incorporate in the ambitious code adopted in that year the following declaration: "Allodial Tenure. The tenure by which all realty is held in this state is under the state or original owner; it is without service of any kind, and limited only by the right of eminent domain remaining in the state." Ga. Code, I86r, sec. 2200.

${ }^{11}$ See Gray, op. cit. supra note 6, secs. 13, 31-34, 744 et seq.; Kales, op. cit. sipra note 6, secs. 13, 302; Zane, Deterninable Fees in American Jurisdictions (I904) I7 Harv. L. Rev. 297, 299 et seq.; Sweet's note in Challis, Real Property (3d ed. I9II) 439; Edwards, Law of Property in Land (5th ed. 1922) 32.

13 "They [statutes of 1787 ] converted all rents upon leases in fee, from rent service, into rent charges or rent seck; and by taking away the grantor's reversion or escheat, they removed the entire foundation on which the power of a grantor to restrain alienation by his grantee formerly rested." DePeyster v. Michael, supra note 9, at p. 505. See also Van Rensselaer v. Dennison, supra note 9, at p. 399; Van Rensselaer v. Slingerland ( 1863 ) 26 N. Y. 580; Van Rensselaer v. Ball (1859) I9 N. Y. Ioo; and dictum of Jessel, M. R., in Collier v. Walters (1873) L. R. I7 Eq. 252, 26I.

${ }^{13}$ The cases are admirably reviewed in the learned article by Prof. R. R. B. Powell, Determinable Fees (1923) 23 CoL. L. Rev. 207. More recent cases holding possibilities of reverter valid interests are Halpin v. School Dist. No. 9 (1923, Mich.) 194 N. W. I005, and Bristol Baptist Church v. Comm. Baptist Con. (1923) 98 Conn. 677 , 120 Atl. 497.

14 "The question has now become wholly immaterial in this country, where every real vestige of tenure is annihilated." 4 Kent, Commentaries, $*_{24}$. See also 
doubt the correctness of this opinion, but in any event, when we are in the game, we hate to see the button elude us. Perhaps we shall find less difficulty in locating it if we first make sure that it is a real button we are seeking.

What then is "tenure" in English law after all? Manifestly it is but a subjective concept; it cannot be an objective reality. Yet all primitive people are disposed to objectify their concepts. The "thinglikeness" of the so-called, incorporeal property rights to the mediaeval mind has been often commented upon. ${ }^{15}$ The fourteenth century lawyer was quite as ready to say that the lord of the Seigniory was seised of the services as that the terre tenant was seised of the land. ${ }^{16}$ To him the vassal's tenement, which was but his relationship ("estate") to his lord, and the rest of the world as well, with respect to the land, came to mean the land itself. Hence he was accustomed to say that the tenement owed the services. ${ }^{17}$ He did not trouble himself to observe that the possessory interests in land, which he called "corporeal" estates, as well as the non-possessory interests, which he considered "incorporeal," were alike without body $;^{18}$ that all "estates" were alike more or less inclusive aggregates of legal relations which the owner, by whatever name called, whether lord, vassal or villein, sustained to the rest of the world with respect to some definite portion of the earth's surface. His goods became his "property," and his land was in his

Washburn, Real Property (6th ed. I902) 59. We are justified in inferring that if a case should arise in which the existence of "tenure" vitally affected the parties' rights, no American court would allow historical consistency to lead it on to archaic and unfit results. See Wallace v. Harmstad, supra note 5; Kavanaugh v. Cohoes Power \& Light Corp., supra note 5.

${ }^{15}$ See 2 Pollock and Maitland, History of English Law (2d ed. Ig05) I24 et seq. To the mediaeval Englishman these rights "are thinglike rights and their thinglikeness is of their very essence. ... .

"The line between the corporeal and incorporeal thing is by no means so clear in mediaeval law as wo might have expected it to be." 2 ibid. 125. This is equally true of Germanic Law. See Huebner, History of Germanic Private Law (Continental Legal History Series, 1918) 184.

${ }^{20}$ See 2 Pollock and Maitland, op. cit. supra note 15 , at pp. 25, 152. So a thief could be seised of his theft. Ibid. I6o.

${ }^{21}$ I ibid. 237. "This, when regarded from the standpoint of modern jurisprudence, is perhaps the most remarkable characteristic of feudalism:-several different persons, in somewhat different senses, may be said to have and to hold the same piece of land." Ibid. "We cannot leave behind us the law of incorporeal things, the most medieval part of medieval law, without a word of admiration for the daring fancy that created it, a fancy that was not afraid of the grotesque." 2 ibid. I49.

1s See Hohfeld, Fundamental Legal Conceptions (I923) 29; Edwards, op. cit. supra note II, at p. I. "Nowhere do we find more sharply marked than in the law of things that feature which above all others characterized the Germanic medieval law; namely, the endeavor to give a tangible embodiment to legal relations that actually existed only in the human mind." Huebner, op. cit. supra note 15 , at p. 184 . 
mind identical with his "real estate." So that mere figment of the legal mind, seisin, so highly metaphysical in its later development, was also objectified. The conveyancer must keep his eye on it with the anxious fidelity of a golf player, lest it somehow escape and "fly back home" to the original feoffor, thus causing all deserted future interests to perish miserably. So it was with "tenures." Littleton regarded tenure as a thing, having somehow an independent and quite sacred existence. ${ }^{19} \mathrm{He}$ classified tenures with the same intense earnestness as a modern scientist classifies butterflies or mountain ranges. Blackstone $^{20}$ followed hard after. Having noted that tenure was nearly always accompanied by fealty ${ }^{21}$ and usually by the duty to render. services, and to do homage, the Great Commentator proceeds with admirable clarity to classify tenures according to the nature of the services to be rendered by the tenant. Having thus set apart the several kinds of tenures, he proceeds to consider the "incidents" of each; and all subsequent writers have followed in his shining wake.

At this point it becomes interesting to strip off these variable incidents of tenure, and lay aside the constant incident of fealty, ${ }^{22}$ in order to take a look at tenure in its nakedness. But after the stripping there is nothing left to see. This tenure seems to be a very ghost of a thing. Take off its covering sheet of "incidents" and it disappears. ${ }^{22 a}$

What is "tenure" then? Most truly we can say it is but a word, a sort of generic term, which serves as a label attached for convenience to groups of greatly varying legal relations which may be created between the occupant of land and his immediate or original grantor, this latter usually being the sovereign power in the existing social order, whether termed King or State. These legal relations are fixed by contract, custom and positive enactment, and naturally vary from time to. time with the social order that controls the land, and are determined ultimately by actual or supposed governmental needs. In mediaeval times the feudal organization determined the character of these rela-

${ }^{19}$ Coke, Littleton, *64 a-*14I b. Bracton, approaching the matter from the standpoint of remedies, and to whom they are available, classifies tenants rather than tenures as such. See Bracton, ff. 7, 7 b, 208 b; I Pollock and Maitland, op. cit. supra note 15 , at pp. 389 et seq.

${ }^{20} 2$ Blackstone, Commentaries, ${ }^{*} 59-*_{102}$.

21 "Very generally the mere bond of tenure is complicated with another bond, that of homage and fealty; the tenant either has done homage and sworn fealty, or is both entitled and compellable to perform both these ceremonies." I Pollock and Maitland, op. cit. supra note I5, at p. 296.

${ }^{22}$ Lands held in Frankalmoign, being given to God, owed no fealty. Coke, Littleton, *66 b, *95 a.

${ }^{2 a}$ It is highly probable that every feoffment by the king or a mesne lord prior to the statute Quia Emptores created the relation of lord and vassal, but there appears to be no reason why William $I$, or one of his tenants in chief, could not, if he had so desired, have made a grant in tenure as free as that created by the grant of the New England Council to the trustees of Plymouth Colony (1628) and the grants of that Colony to settlers. See infra notes 5 I and 52. 
tions; but with the passing of the feudal order came radical changes, just as we should expect, either by the slow operation of changing custom, or by express enactment, as, for example, by the provisions of Magna Carta, modifying the rules as to aids ${ }^{23}$ and the marriage of vassal wards, ${ }^{24}$ by the statutes of De Donis ${ }^{25}$ and Quia Emptores, ${ }^{28}$ by the sweeping provisions of the statute (I660) I2 Car. II, c. 24, formally abolishing those archaic feudal duties and liabilities of lay tenants that had ceased to have any social significance and, therefore, any legal force; and most recently by the English Law of Property Act of 1922,27 abolishing copyhold and customary tenures, so that lands so held become "freehold land." Even escheats are abolished. ${ }^{28}$

It is well enough to have a general name to apply to this general kind of varying aggregates or bundles of legal relations, which, in one form or another, always must exist between the tenant of land and those from whom he had it mediately or immediately, or, to drop into traditional language, those from whom he holds it. It is even well, though dangerous, to group together those relationships which have a common operative fact of distinguishing character, such as the freedom or baseness of the service to be rendered, and call them respectively free tenures and base tenures; or even to redivide these groups and call the smaller groups military tenures, socage tenures, copyholds, and the like, always provided we resist the common temptation to consider, these several kinds of tenures as having a separate existence, independently of the legal relations composing them.

The very great importance of "tenure" in English law, and, indeed, in American law, is due to the economic and political significance of some of the legal relations within the connotation of this term. This will become more clearly apparent upon a more precise analysis of one of the important feudal tenures, tenure in chivalry, let us say, as it existed prior to the statute Quia Emptores, by setting out the more significant of the legal relations created. Let us assume a feoffment by the Crown to $A$ and his heirs to hold in knight's service. $A$, the feoffee, acquired by the feoffment many valuable rights, powers, privileges, and immunities. He had the right of exclusive possession and enjoyment of the land and the right to demand of his lord, the King, protection in his possession. The lord, in turn, owed corresponding duties to the tenant. A had also the power of subinfeudation; that is, he could with the consent of his lord, and upon payment of a fine, con-

${ }^{23}$ Cap. I2, I5.

"Cap. 6.

" (1285) r3 Edw. I, st. I.

${ }^{28}$ (I290) I8 Edw. I, st. I, cc. I-3.

${ }^{27}$ (I922) I2 \& I3 Geo. V, c. I6, secs. I28-144.

${ }^{2 s} \mathrm{Ibid}$. sec. 148 . Lands of one dying intestate and without heirs go to the Crown, or the Duchy of Lancaster, or the Duke of Cornwall, as bona vacantia Ibid. sec. I50, (I), (vii). 
vey part of the land to another, and by reserving services from his grantee, put himself in the position of a mesne lord, with all the rights and powers incident to that relation. If the feoffment was of a manor, he acquired yet other rights, powers and privileges. But it is in the duties and liabilities of the tenant and the corresponding rights and powers of the lord that we find the significant economic and political elements of the tenure relationship. The tenant has taken an oath of fealty to his lord, and perhaps has done homage. He is under a solemn duty to be obedient, loyal and faithful. He owes to his lord the honorable but highly uncertain and undesirable duty of military service, and also the duty of suit at the lord's court. These duties were burdensome enough, but the chief cause of the tenant's discontent lay in the heavy liabilities under which he must hold his land, correlative to numerous powers reserved by his lord of a kind peculiarly capable of arbitrary exercise and abuse. The lord might retake-his land by escheat in case of his conviction of felony, or failure of heirs, or by distress in case of failure to render services due. ${ }^{28} \mathrm{He}$ might levy fines and reliefs, and even aids, all of which were encumbrances upon the land since they could be enforced by distress, while his powers to claim wardship, primer seisin and marriage, in case the tenant should be so unlucky as to die leaving an infant heir, so burdened the fee as to make the situation of the tenant intolerable. The social organization under which were created these legal relations so burdensome to the tenant, in early times found justification in providing a crude scheme of local government and a still cruder system of national defense, which must have been highly inefficient at its best; as indicated by the early commutation of personal military service into money payments known as scutage $^{30}$ But it persisted long after the need for it had ceased, partly through the law's inertia, and partly because: the land-holding class fully realized that control of the land gave control of those who made their homes on the land and gained a livelihood from it. It was against this control in the landed nobility arising from the powers which feudal law allowed grantors to reserve that the English people waged ceaseless and ultimately successful warfare on both sides of the Atlantic. One of the most successful assaults upon this method of preserving land control is marked by the enactment of the statute Quia Emptores. By that act all grantors of land in fee, except the King,

\footnotetext{
${ }^{2}$ The law is so stated in 2 Blackstone, Commentaries, $*_{45}$ and in DeLancey $v$. Piepgras (1893) 138 N. Y. 26, 39. It was on this theory that N. Y. Laws, 1918, ch. 222, authorized the comptroller to sell lands on which quit rents were due and unpaid, and after a two year period of redemption, to give a deed therefor. See DeLancey v. Piepgras, supra. But it seems clear that as early as Bracton's day the lord's power of distress extended only to chattels found on the land. See I Pollock and Maitland, op. cit. supra note 15 , at p: 353 ; Fowler, op. cit. supra note 9, at p. 45 .

${ }^{20}$ See I Pollock and Maitland, op. cit. supra note 15 , at p. 356.
} 
were in effect prevented from reserving the obnoxious powers. ${ }^{31}$ This enactment was eminently consistent with the course of progress in industry and government. By I290, the date of that famous statute, the King's courts had pretty well extended the King's justice over the land, and the King's administrative and governmental authority had so far encroached upon the local governmental powers of the lords, ${ }^{32}$ that there could be found no just reason for giving to a mesne lord making a feoffment powers which, though limited, were in their nature governmental.

Thus after the statute Quia Emptores these powers of control over land thereafter granted for the most part remained with the Crown, where they belonged, if anywhere, and with the lords of the existing manors, who still retained considerable administrative and political authority. But even in the Crown these reserved powers gradually lost their significance with the passing of conditions that gave rise to them. ${ }^{83}$ The effort of the Stuarts to revive them cost Charles I his head, and with the Restoration Charles II gave his assent to an $\mathrm{Act}^{34}$ of Parliament that in effect abolished nearly all of those dangerous and oppressive powers reserved to the feudal lord which rendered the tenant's title to his land insecure and on that account gave to the lord a measure of control over the tenant highly obnoxious to the liberty-loving Englishman. Some of the legal relations included within the complex feudal concept denominated "tenure" still remained, but they were mostly of the innocuous kinds incident to socage and copyhold tenures. There was still fealty owed by the tenant to his chief lord, but this amounted to no more than liability to lose the land by escheat in case of conviction of a felony, ${ }^{35}$ an idea to which the Englishman was accustomed and did

I This statute (1290) enacted only five years after the statute De Donis (1285), a signal victory of the land-owning class in the long struggle over land control, was probably regarded at the time as in the interest of the "great men," as indicated by its preamble. Its ultimate operation in freeing the land was probably not foreseen.

I Pollock and Maitland, op. cit. supra note 15, at pp. 528, 532; Jenks, Short History of English Law (1912) 7x.

${ }^{23}$ See Kales, op. cit. supra note 6 , sec. 8.

" (1660) I2 Car. II, c. 24.

${ }^{35}$ The distinction between fealty and homage is well stated in Chitty's note in 2 Blackstone, Commentaries, *45. An opinion appears to prevail that the common law right of distress is necessarily dependent upon the existence of fealty. See opinion of Woodworth, J., in Cornell v. Lamb (1824, N. Y. Sup. Ct.) 2 Cow. 652, 656; also Kavanaugh v. Cohoes Power \& Light Corp., supra note 5, at p. 6I4. The connection, which is only incidental, is thus explained in Comyn, Landlord and Tenant (2d ed. I834) 97, as quoted in Wallace v. Harmstad, supra note 5, at p. 498. "The fealty was always inseparably incident to the reversion; and therefore never could be lost to the ultimate lord. But the rent, though generally incident to the reversion, might, at the will of the feoffor, be severed from it, and reserved to the feoffor himself, provided such reservation were by deed. But the fealty, being now severed from the rent, the remedy by distress, which was only given in respect of the fealty, became lost to the feoffor." 
not particularly resent. ${ }^{38}$ He thought no more of it than the American voter does of his oath of allegiance. The personal services reserved had practically all been commuted to money payments, known as quit rents, which were usually of inconsiderable amount. ${ }^{37}$ In some parts of England, notably in the Palatinate of Durham, there seems to have been difficulty in enforcing payment of even these nominal quit rents, ${ }^{38}$ but for the most part they caused little disturbance. The chief lord's right to reliefs on intestate succession still remained, as did his power of distress to enforce these shadowy remnants of the old feudal "incidents." But these rights and powers of the chief lord, who it must be remembered was usually the crown, having ceased to have any substantial value, came less and less to be insisted on and are now for the most part forgotten, so that a recent English writer might well enough say, ${ }^{30}$ "A tenant in fee simple of land is now practically full owner of the land." In short the difference between lands "held" by tenure in England and those "owned" allodially in the United States is little more than a difference in words. We shall express the same idea more exactly if we say that in England to-day the chief lord, usually the Crown as representing the State, does retain certain legal relations with respect to land occupied by tenants in fee, but, barring distress as of common right, none of these relations have any importance save the power of retaking the land by escheat upon failure of heirs and by eminent domain; and these powers equally exist in the United States.

The first royal grants of vacant lands in the New World were made during the critical period when the Stuarts were struggling to re-establish the waning feudal powers of the Crown. It was but natural that patents were in feudal form, the land to be held in free and common socage, reserving some nominal services, like the annual render of two beaver skins ${ }^{40}$ or "an Indian arrow of these parts." patents did not expressly confer upon the patentees the power of subinfeudation, though it seems to have been assumed ;2 but later grants in unmistakable terms gave this power, "The Statute Quia Emptores Terrarum, lately published in our Kingdome of England, in any wise not-

${ }^{30}$ By the Forfeiture Act of 1870 (33 \& 34 Vict. c. 23) sec. I, all forfeitures and escheats for treason and felony were abolished. This follows the constitutional rule generally prevailing in the United States. See U. S. Constitution, art. III, sec. 3. Stimson, Federal and State Constitutions (1908) 79, 182.

${ }^{37}$ For an interesting account of the slow process, see Vinogradoff, Villainage in England (1892) 288 et seq.

${ }^{23}$ See Bond, The Quit Rent System in the American Colonies (1919) 28.

so Topham, Real Property (3d ed. Ig2I) 20; Edwards, op. cit. supra note II, at p. I2.

¿0 Patent to William Penn, I68x. See supra note 2.

¿ Patent to Lord Baltimore, I632. (3 Thorpe, op. cit. supra note 1 , at pp. I669, I67x.)

a Bond, op. cit. supra note 38 , at p. 31 . 
withstanding." 43 In all of the original Colonies, save Massachusetts, Rhode Island and Connecticut, grants to settlers whether by royal governors on behalf of the Crown or by proprietaries as mesne lords, were made in free and common socage. The service reserved was usually the payment annually of a small sum of money, ${ }^{44}$ but sometimes it required a render in kind, "yielding and paying" each year one beaver skin, or an ear of corn, or "one white perch" in case of the grant of a fishery ${ }^{45}$; but all services, whatever the form, were commonly called quit rents.

The only elements of Colonial socage tenure that assumed any significance were fealty, escheat and quit rents, and the power of the chief lord, usually expressly reserved, ${ }^{4 \theta}$ to enforce payment by distress. Fealty and escheat seldom came to public attention, ${ }^{47}$ but quit rents soon presented a dangerous issue. Throughout the Colonial period efforts to collect quit rents were attended with much difficulty and little success, and the levying of distress upon the lands of delinquent tenants, causing great resentment and public indignation, served as one of the principal

Ibid. 3I et seq. The charter to William Penn (I68I) empowered him, his heirs and assigns to make feoffments "to have and to hold to them the said person and persons willing to take or purchase, theire heires and assignes, in ffee-simple or ffee-taile, or for the termes of life, or lives or yeares, to be held of the said William Penn, his heires and assignes, as of the said Seigniory of Windsor, by such services, customes and rents, as shall seeme fitt to the said William Penn, his heires and assignes, and not immediately of us, our heires and successors. . . . The Statute made in the parliament of Edward, sonne of King Henry, late King of England, our predecessor, commonly called The Statute Quia Emptores Terrarum, lately published in our Kingdome of England in any wise notwithstanding." 5 Thorpe, op. cit. supra note I, at p. 3042. Since the statute Quia Emptores did not apply to grants by the King, he might lawfully waive its application to his grantees. At least, it was so held in People v. Van Rensselaer (1853) 9 N. Y. 291. To the same effect is Coke, Littleton, ${ }^{*} 98 \mathrm{~b}$ and Challis, $o p$. cit. supra note II, at p. 20.

"On Feb. 15, 1796, Stephen Van Rensselaer made a grant of certain land to Jacob Dietz, his heirs and assigns "yielding and paying therefor yearly and every year during the continuance of this grant, unto the said Stephen Van Rensselaer, his heirs or assigns' .... thirty bushels, \&c., of good winter wheat, ... f four fat fowls, and one day's service with carriage and horses." $V a n$ Rensselaer v. Hays (1859) I9 N. Y. 68, 69.

"See Cadwalader, Law of Ground Rents (1879) 20 et seq. An interesting feudal grant made by Thomas and Richard Penn, as proprietaries of Pennsylvania, in 1764 , to trustees for the use of the town of Easton, reserving an annual render of "one Red Rose," is set out in the report of Stuart v. Easton (1898) r7o U. S. 383,386 , I8 Sup. Ct. 650, 652 .

${ }^{4}$ See Jackson v. Schultz (1820, N. Y. Sup. Ct.) I8 Johns. I74, 180; DePeyster v. Michael, supra note 9, at p. 502; Fowler, op. cit. supra note 9, at p. 32.

"See Cornell v. Lamb, supra note 35, at p. 654; Fowler, op. cit. supra note 9, at p. 33. Seignorial rights of fealty and escheat seem never to have been exercised in New York, nor were the governmental powers granted to the lords of manors created, of which there were a large number (see list in People v. Van Rensselaer, supra note 43 , at p. 306), ever exercised. See ibid.; DeLancey v. Piepgras, supra note 29 , at pp. 36,38 . 
inducing causes of that state of the public mind that made possible the Revolution..$^{4}$

The Puritans of New England, who had come to the New World for the very purpose of escaping the restrictions of the Old, quickly perceived what was the real meaning of quit rents reserved; that by submitting to quit rents and the power of the overlord to collect them by distress they subjected themselves to the will of another and sacrificed the independence which they had sought to win at so heavy a cost. Undoubtedly the New England Council considered that it had the power, under King James' Charter of $1620,{ }^{48}$ to exact quit rents, and laid its plans to do so, ${ }^{50}$ but its grant in 1628 to William Bradford and his associates, in trust for Plymouth Colony, reserved no quit rent save one-fifth of the gold and silver mined within the granted territory ${ }^{5 x}$; and thereafter grants made by the Colony to settlers were in "free tenure" with no reservation of quit rents or other feudal incidents. ${ }^{52}$ The patent to the Massachusetts Bay Company, under the same date, expressly conferred the power to make grants with reservation of quit rents, ${ }^{53}$ but few, if any, such reservations were made, and in I64I the General Court declared that land tenure should be free. ${ }^{54}$ The free tenure thus established in Plymouth and Massachusetts Bay Colonies spread over the whole of New England, despite the efforts of Mason and Gorges to establish their proprietary claims to quit rents and other feudal rights in the New Hampshire and Maine territories.55 The efforts of Charles II and of James II, through Sir Edmund Andros, their Captain General, to re-establish feudal tenure with quit rents, proved unavailing against the stout resistance of the New Englanders, and long before the Revolution free tenure, which might just as well be called allodial ownership, was firmly established. ${ }^{56}$

\footnotetext{
is See Bond, op. cit. supra note 38 , at pp. $48,450-459$.

3 Thorpe, op. cit. supra note I, at pp. I827, I832.

${ }^{\infty}$ Bond, op. cit. supra note 38 , at p. 35 .

" 3 Thorpe, op. cit. supra note $I$, at pp. I84I, 1844. For the similar charter granted Connecticut in 1662 , see I Thorpe, op. cit. 529, 536.

sond, op. cit. 38 .

Ibid.

The language of this bold declaration is characteristic of the men and the time "It is also Ordered, and by this Court Declared, That all our Lands and Heritages shall be free from all Fines and Licenses, upon Alienations, and from all Hariots, Wardships, Liveries, Primerseizins, year, day and waste, Escheats and forfeitures upon the Death of Parents or Ancestors, natural, unnatural, casual or judicial and that for ever." Colonial Laws of Massachusetts (Reprint, I887) 88. To the same effect was the act passed by the General Assembly of Connecticut in 1650. See I Conn. Colonial Records, at pp. 536, 537.

${ }^{85}$ Bond, op. cit. 52-61.

st See ibid. 48. The end of the struggle was in effect marked by the charter given by William and Mary in $169 \mathrm{~g}$, which granted the territory claimed by the Province of Massachusetts Bay to the inhabitants thereof, in free and common socage, reserving no service save the fifth part of precious metals and stones discovered,
} 
But in New York and the other colonies to the south, conditions were more favorable to the establishment of quit rents and the other incidents of tenure in free and common socage, and the opposition of the settlers, while persistent and rebellious at times, was not so successful. While the collection of quit rents was resented and resisted, throughout these colonies, sometimes by force, ${ }^{57}$ yet it is noticeable that the right of the feudal lord, whether King or proprietary, to his services reserved, in the form of quit rents, to his reliefs, his fines for alienation and escheats, remained almost unquestioned up to the time of the Revolution. ${ }^{58}$ There was, however, much question as to the right of the overlord to use the revenue derived from quit rents for other than local governmental purposes. The Colonists came early to feel that the reservation of quit rents was but a form of land tax, and that the revenue so secured should of right be devoted to public uses.59 This made it more difficult to enforce payment of quit rents in the Proprietary Colonies than in the Crown Colonies, even though the Proprietaries possessed the powers and responsibilities of government, and when quit rents became payable to overlords without governmental powers, such collection became well-nigh impossible. ${ }^{60}$ Even in Virginia, which became a Crown Colony as early as 1624 , and where quit rents were most firmly established and successfully collected, the grant by Charles II, in I672, of all quit rents in Virginia for a period of $3 I$ years, threw the whole colony into an uproar ${ }^{81}$ and contributed much to the discontent that found expression in Bacon's Rebellion. There is much evidence that the Royal Government also regarded the receipts from quit rents as public revenue. In Jamaica and other West India Colonies, quit rents reserved were commuted into an export duty ${ }^{62}$; and in I68I, after the subsidence of Bacon's Rebellion, the Privy Council declared that its policy in future would be to reserve all revenue from quit rents for the expenses of local government "'as they were originally intended." "ss

This summary statement has made it sufficiently clear that whatever historical reasons there might have been to justify the continuance in the England of the Stuarts of such feudal tenures as then remained, they had no application to land grants in the New World; that the colonists bitterly resented the reservation by the sovereign or other overlord of powers that gave him personal control over their lands; that

and confirming all grants theretofore made by the General Court. See 3 Thorpe, op. cit. 1870,1877 .

"See account of the riots in East Jersey, Bond, op. cit. Ioo.

${ }^{s s}$ Ibid. 457; Matthezes v. Ward (I839, Md.) 10 G. \& J. 443, 450.

${ }^{s 0}$ Bond, op. cit. $45,66,179,18 \mathrm{I}, 186$.

${ }^{\infty}$ Ibid. 5I, 53.

at Ibid. 62.

abid. 33, 43, 440

"Ibid. 66. 
they resisted it everywhere and successfully repudiated it in New England; and that quit rents tended to assume the character of a land tax, a tax most heartily opposed because its levy, collection and appropriation were all without the control of the local governing bodies. Such being the situation when the newly independent states found themselves in 1776 masters of their own destiny, we should expect action to carry out the popular desire to be rid of the claims of overlords which they regarded as incompatible with the sovereignity of an independent state $^{64}$ and dangerous to their personal liberty and the security of their land titles. ${ }^{65}$ But however common the popular desire, the methods adopted by the new states to effect this desire were far from being uniform. The New England states having already, in stout Puritan fashion, established free land tenure, were in no need of legislative action, but nevertheless the cautious legislators of Connecticut deciared that ${ }^{66}$ "Whereas by the establishment of the independence of the United States, the citizens of this state became vested with an allodial title to their lands; . . . . every proprietor, in fee simple, of lands, has an absolute and direct dominion and property in the same." In May, I776, the Virginia Assembly declared that all quit rents payable to the Crown should thereafter be paid into the treasury of the state, ${ }^{67}$ and in I779 summarily abolished them together with "all other reservations and conditions in the patents or grants of land" from the Crown, further declaring ${ }^{68}$ "that all lands thereby respectively granted, shall be held in absolute and unconditional property to all intents and purposes whatsoever, in the same manner with lands hereafter to be granted by the commonwealth." But it was not until 1785 that the quit rents reserved under the Fairfax proprietary grants in the "Northern Neck," having become payable to an alien heir, were confiscated and discharged. ${ }^{\text {s }}$

In dealing with the incidents of tenure New York proceeded with the greatest caution, probably because of the quit rents payable to loyal owners of great manorial estates in the Hudson and Mohawk

\footnotetext{
" Ibid. 214. The preamble of the Act of 1780 (Laws of I780, ch. I8, I Dorsey's Laws of Maryland, 1840, 158 ) recites that "whereas the payment of quitrent, from the declaration of independence, both ceased, and of right ought to cease, being an acknowledgement of seignory incompatible with the independent sovereignty of this free and independent state. ..." In rejecting the claim of the proprietary, Henry Hartford, to receive quit rents after the Revolution, the Maryland Senate indignantly refused to "place the free people of Maryland in the degraded position of tenants to a superior lord, a foreigner and a British subject." " Bond, op. cit. 214.

${ }^{*}$ See Divesting Act of I779, sec: 2, I Carey \& Bioren's Laws of Pennsylvania, I803, 230.

${ }^{e s}$ Act of 1798 (Conn. Rev. Sts. 1821, tit. 56, ch. I, sec. I).

${ }^{67} 9$ Hening, Statutes at Large (I82I) ch. 5, sec. 7 .

${ }^{e s}$ Io ibid. 64 .

${ }^{\circ}$ I3 ibid. II3.
} 
valleys. The "Act Concerning Tenures," passed in 1787 , re-enacted in substance the English statutes of Quia Emptores and I2 Car. II, c. 24, carefully saved "any rents certain or other services incident or belonging to tenures in common socage, due or to grow due to the people of this state, or any mean lord, or other private person, or the fealty or distresses incident thereunto," and finally declared that all grants made or to be made by the state should be held by tenure "allodial and not feudal." By the revision of 1830 it was declared that ${ }^{71}$ "the people of this state, in their right of sovereignty, are deemed to possess the original and ultimate property in and to all lands within the jurisdiction of the state; and all lands to which the title shall fail from a defect of heirs, shall revert or escheat to the people." The act then declared such lands to be allodial, a term which the act proceeds to define:72 "so that, subject only to the liability to escheat, the entire and absolute property is vested in the owners, according to the nature of their respective estates." "All feudal tenures of every description, with all their incidents" were then abolished, with the same saving as in the Act of 1787. Lest there be any doubt as to the destruction of feudal tenures, these provisions were incorporated in the Constitution of $1846^{73}$ and are retained in that now existing. ${ }^{74}$

For a time the quit rents which became payable to the state as successor to the English Crown were regarded as assets from which appropriations could be made, ${ }^{75}$ and statutes were passed authorizing their collection. ${ }^{78}$ It is probable that the efforts to make collection were not successful, and they seem not to have been continued after the revision of 1830 .

In East Jersey there were many quit rents which had been reserved on proprietary grants, that belonged to loyal citizens. To protect these the New Jersey legislature in 1795 passed an act ${ }^{77}$ almost identical with the New York Act of 1787 referred to above, declaring that all grants by the state should be by allodial tenure, but carefully saving all rent services and other tenurial incidents of grants formerly made by the Crown or other lords. The innocuousness of the legal relations thus preserved is clearly indicated by the fact that this curious survival of America's misshapen feudal past, the Act of $x 795$, still remains

\footnotetext{
${ }^{70} 2$ Jones \& Varick's Revision, Laws of New York, I789, at p. 67.

"I N. Y. Rev. Sts. 1830, at p. 718, sec. I.

Ibid. sec. 3.

Art. I, secs. II, I2, I3.

"Constitution of 1894, art. I, secs. Io, II, r2.

${ }^{75}$ Bond, op. cit. 284.

${ }^{70}$ N. Y. Laws, I8r9, ch. 222; Laws, 1825, ch. 251. See DeLancey v. Piepgras, supra note 29 , at p. $4 \mathrm{I}$, where is recounted a sale of land in 1826 for failure to pay quit rents due.

"Act Concerning Tenures, Feb. 18, I795 (N. J. Rev. Laws, I821, I66).
} 
unchanged in the statute law of New Jersey, where it operates only to cast an occasional ghostly cloud upon a land title. ${ }^{78}$

The important proprietary colony, Maryland, upon attaining statehood, contented itself with abolishing quit rents, ${ }^{79}$ but we are assured by the Supreme Court of Maryland that the effect of this seemingly fragmentary statutory treatment was to abolish all tenures and make the land of the state allodial.80 But the other great proprietary state, Pennsylvania, did not succeed in shearing off her feudal past quite so neatly. It seems to have been recognized that the quit rents payable under the proprietary grants were the private property of the Penns, and not public assets. ${ }^{81}$ This opinion reflects great credit upon the fair-mindedness of the Pennsylvania Quakers, but not so much as the provision in the "Divesting Act" of $1779,{ }^{82}$ confiscating the rights and abolishing the political powers of the proprietaries, by which $\sum_{1} 30,000$ was granted to the Penn family in recognition of the debt owed by the people of the state to the memory of William Penn. It seems, however, to be generally agreed that this act did not destroy tenure in Pennsylvania. ${ }^{83}$ The statute Quia Emptores has never been in force in that state, ${ }^{84}$ and therefore rent reserved, even on a grant in fee, is rent service, which is apportionable ${ }^{85}$ and enforceable by distress. ${ }^{86}$ Such conveyances in fee are said to create two estates in fee, one in the land and the other in the rent issuing out of the land. ${ }^{87}$ But these estates are separate and distinct; so distinct that when a testator conveys land previously devised, and dies, the devise is wholly abated, and does not carry the "ground rent" reserved. ${ }^{88}$ However this may be, since Pennsylvania has not by statute or by constitutional provision abolished tenures or declared land to be allodial, it is usually said that tenure still exists in Pennsylvania. In South Carolina we are not left to inference for the act of $1712,^{89}$ declaring that the only tenure of lands in that colony should be that in free and common socage, still remains

${ }^{78}$ N. J. Comp. Sts. Igro, Conveyances, secs. 9-r4. See Bond, op. cit. Io7.

Iaws, I780, ch. I8, sec. 2. I Dorsey's Laws of Marylanid, 1840, at p. I58.

${ }^{80}$ Matthews v. Ward (1839, Md.) 10 G. \& J. 443, 45 I.

Cadwalader, op. cit. supra note 45 , at pp. 45 et seq.

See supra note $6_{5}$.

"Ingersoll v. Sergeant (1836, Pa.) I Whart. 337; Cadwalader, op. cit. supra note 45 , at p. 50; Gray, op. cit. supra note 6 , sec. 26 . The very positive declaration in Wallace v. Harmstad, supra note 5 , that all lands in the state were made allodial by the Divesting Act, has not been accepted as law. Cadwalader, op. cit. supra note 45 , at p. 50 .

ss Ingersoll v. Sergeant, supra note 83 ; Gray, op. cit. supra note 6 , sec. 26.

${ }^{85}$ Ingersoll $v$. Sergeant, supra note 83 .

${ }^{80}$ Cadwalader, op. cit. supra note 45, at pp. 62, 222 et seq.

${ }^{87}$ Bosler v. Kuhn (I844, Pa.) 8 W. \& S. I83; Cadwalader, op. cit. I94.

${ }^{2}$ Skerrett v. Burd (I836, Pa.) I Whart. 246; Girard v. Mayor of Philadelphia (I833, Pa.) 4 Rawle, 323; Cadwalader, op. cit. I38. But see ibid. 90, note.

${ }^{8}$ See Act of Dec. 12, I712, sec. 5 (Grimke, Public Laws, 1790, at p. 99). 
unchanged. ${ }^{\text {o }}$ There, too, it is said the statute Quia Emptores is not in force. ${ }^{91}$ Quit rents, completely ignored, seem to have faded out of existence.92

But what shall we say of those other states that have not taken the trouble to declare tenures abolished or lands to be allodial, such as Delaware, North Carolina, and Georgia? It is true that in the North Carolina constitution of $1776^{93}$ and that of Georgia of $1798,{ }^{94}$ there are recitals to the effect that the "property of the soil in a free government" is "one of the essential rights of the collective body of the people," and that a late statute ${ }^{95}$ in Georgia declares that all land is allodial, that is, held of the state; but these purport rather to declare than to change an existing fact. Did "tenures" continue in these states merely because they were not abolished? Is the socage tenure in South Carolina dead from neglect, or is it only sleeping? In what respect do land titles in Delaware where the pre-revolutionary claims of the proprietaries upon landholders were simply ignored after the Revolution, ${ }^{96}$ differ from those in New Hampshire where John Mason's claims of feudal rights and powers had been abandoned and forgotten long before the Revolution ?07 Manifestly, not at all. In each state the tenant in fee holds his land "absolutely" but yet subject to the state's right to have it by escheat in case he dies intestate without heirs, and to the state's power to take possession of it in the exercise of its eminent domain, to seize it for non-payment of taxes and to regulate its use so that it shall not become a public nuisance; and this is just as truly allodial ownership as if it had been so declared both in the statutes and the constitution.

What then is the answer to our question, Do we have tenure in the United States? The short answer is, yes, the American holds his lands of the state ${ }^{98}$ in which it lies just as truly as the Englishman holds his of the Crown, and the incidents of this tenure are at the present time very nearly the same in both cases. But this short answer is of little value. We must make a longer one in this wise: The term "tenure," which has always served but as a convenient label to attach to certain groups of relations between grantors and grantees, mediate or imme-

${ }^{\infty}$ S. C. Code, 1912, sec. 3443. ${ }^{12}$ See Gray, op. cit. sec. $27 .{ }^{82}$ Bond, op. cit. 348.

${ }^{23}$ See Bill of Rights, N. C. Constitution, I776, art. xxv (5 Thorpe, op. cit. 2787 , 2788). See also Connor, The Granville Estate and North Carolina (I914) 64 U. PA. L. Rev. 67I.

- Ga. Constitution, 1798, art. I, sec. 23 (2 Thorpe, op. cit. 781, 794).

"In the Code of I86I the following declaration first appeared as sec. 2200: "Allodial Tenure. The tenure by which all realty is held in this State is under the State as original owner; it is without service of any kind and limited only by the right of eminent domain remaining in the State." It remains unchanged as sec. 3623 of the Code of rgrr.

Bond, op. cit. r7r.

${ }^{97}$ Ibid. 60.

"Since the act of 1787 concerning tenures .... it has not been possible to create a feudal tenure in this state, and, consequently, none of the peculiar incidents of that tenure attach to an estate granted by one citizen to another since that act took effect." Van Rensselaer v. Demison (I866) 35. N. Y. 393, 399. It trans- 
diate, recognized and enforced by the law, has no longer any utility except when applied to estates less than a fee simple. The most significant of the relations contained within the groups so labeled in mediaeval times have long since ceased to be recognized by the law. Particularly is this true of those powers of control reserved by the feudal grantor which bore the names fealty, homage, wardship, aids, marriage, reliefs and fines, distress and escheat. The liabilities which corresponded to these powers of the lord, as well as the duty to render services which were the right of the lord, were resisted by English tenants with growing success. Only a few survived to be brought over to the American colonies, and they in a weakened condition. These survivors fared worse in the unsuitable soil of the New World than in the Old, but at this time on both sides of the water they have either ceased to exist or ceased to have any significance as means of economic control. Fealty has faded into the pale duty of allegiance ${ }^{99}$ due no more from the land tenant than from other citizens. Homage is forgotten. Wardship, aids, marriage and fines, with uncertain and burdensome services, fell by the statute (I660) I2 Car. II, c. 24. Reliefs are not demanded. ${ }^{100}$ Escheat no longer robs the innocent heirs of felons, and survives only to give to the state the lands of one deceased when there appear no heirs, devisees or creditors to claim them. In the United States distress, as a common law power incident to tenure of land in fee, appears to exist only in Pennsylvania. Elsewhere it survives only in a statutory form to compel payment of rent by a tenant of a particular estate. What then have we left of our "tenure" relations? In America the state is the only overlord, while in England, after the Law of Property Act of I922 goes into effect, the only overlord will be the Crown, except in the Duchy of Cornwall. This overlord still has in effect the non-oppressive power of escheat. His power of eminent domain, while properly a relation between overlord and tenant, ${ }^{201}$ has always been recognized as a prerogative of sovereignty and

ferred the seigniory and escheat to the peoplo of this state, who then became the chief lords of the fee. Van Rensselcer $v$. Hays (1859) I9 N. Y. 68; De Peyster v. Michael (I852) 6 N. Y. 467.

While the statute of South Carolina (supra note 89 ) declares that lands in that state are held in free and common socage, the constitution declares that the people of the state "possess the ultimate property in and to all lands within the jurisdiction of the State." Constitution, I895, art XIV, sec. 3. The same provision is found in the Wis. Constitution, I848, art. IX, sec. 3.

"For the close connection between "allegiance" to the sovereign and "fealty" to the feudal lord, see I Pollock and Maitland, op. cit. 299; 2 Blackstone, Commentaries, ${ }^{*} 53 ; 3$ Kent, Commentaries, ${ }^{*} 511,{ }^{*}{ }_{512}$. See also Coke, Littleton, *686; I Hale, Pleas of the Croun (1778) 62, 70.

"Fealty is not, in fact, due on any tenure in this state, it is altogether fictitious." Woodworth, J., in Cornell v. Lamb, supra note 35, at p. 657 .

${ }^{100}$ Topham, op. cit. supra note 39, at p. I4. Modern death duties, or inheritance taxes, levied by the state are similar in nature to the feudal reliefs.

${ }^{102}$ The "right of eminent domain" recognized in all times and under all systems 
not regarded as an incident of tenure. The services owed to the overlord, which in later feudal times were commuted to money payments and in America were known only as quit rents, in modern times take the form of taxes assessed on land and are merged in the larger sovereign power of general taxation. The undoubted power of the state to regulate and control the tenant's use of his land so as to protect the public from nuisance ${ }^{102}$ is in one sense a liability of land tenure, but that, in turn, is also without feudal associations.

Thus we see that in spite of the declaration of statutes and constitutions, the "ownership" of a tenant in fee is far from being absolute. His rights, powers and privileges with respect to his land, which make up his ownership, are very much restricted by the powers retained by the state. Therefore if we wish to use the term "tenure" to indicate restricted ownership of land with retention of some legal interests by an overlord, we may well enough say that the tenant in fee of lands in any of our states holds of the state. But the group of legal relations found here to exist between state and landowners has so very little in common with those groups called "tenures" in the Middle Ages, that the use of the term will scarcely prove helpful.

But can we in any case predicate "tenure" of the relation between private grantor and grantee of land conveyed in fee in the United States? We are accustomed to say that the statute Quia Emptores made impossible any tenure between grantor and grantee in case of conveyances in fee after its date (I290), and that, since that statute is probably in force so far as needed in all of our states except Pennsylvania and South Carolina, there can be no such tenure anywhere except in those states. ${ }^{103}$ But let us note that Quia Emptores merely provides that any freeman may sell his lands or any part of them "so that the feoffee shall hold the same land or tenements of the chief lord of the same fee, by such service and customs as his feoffor held before." This undoubtedly operated to substitute the new feoffee for the old as far as his relation to the chief lord was concerned, so that he "shall be forthwith charged for the services." It is clearly established that it also operated to negative the creation, by mere customary law, of any tenurial relation between feoffor and feoffee in fee simple. ${ }^{104}$

of law as. inherent in sovereignty, is the power of the sovereign to resume possession of land or goods whenever the public welfare requires it. I Nichols, Eminent Domain (I9I7) I et seq. As said by Leonard, J., in Biddle v. Hussman (I856) 23 Mo. 597, 600: "The condemnation was a resumption by the state of her original title to the land under her right of eminent domain."

${ }^{102}$ That tht State may take property, real or personal, when used in violation of law, when the public interests clearly requires, is now well recognized. See State v. Lane (1914) I26 Minn. 78, 147 N. W. 95I. In Gray v. Thomas (r923, Iowa) I94 N. W. $96 \mathrm{I}$, the power of the State to destroy shrubhery harmful to the public was upheld.

${ }^{108}$ See Gray, op. cit. sec. 25.

${ }^{\text {sor }}$ Coke, Littleton, *I43 a ; I Tiffany, Real Property (2d ed. I920) 26. 
But-does it mean that the feoffor after I2go could not by express contract retain to himself and his heirs any interest at all with respect to the land conveyed? Clearly it did not, for if the feoffor in fee reserved rent and also the power of distress, he was said to have a rent charge, ${ }^{105}$ a highly significant interest in the land. It is true that the lawyers of Coke's day explained this transaction as a grant of a rent charge by the feoffee, ${ }^{108}$ but the result was that the feoffor retained a very valuable right and power in the land. When the deed of feoffment included a condition of forfeiture with power of re-entry ${ }^{107}$ for non-payment of rent, we find existing by express contract between grantor and grantee in fee some of the most important legal relations which arose before the statute Quia Emptores as part of a larger group created by contract largely implied from custom. ${ }^{108}$

Many other examples may be given of instances in which after the statute Quia Emptores the grantor in fee. was allowed to convey a restricted interest in the land, that is, to retain some of the aggregate of legal relations which he, as tenant in fee simple, possessed. Thus the mortgagor, though conveying in fee simple, retained the power to defeat the grantee's estate by paying his debt at the law day. So the grantor reserving a power of entry and forfeiture for breach of any lawful condition subsequent, retained a valuable interest in the land. Likewise in case of a conveyance on special limitation creating a determinable or base fee in the grantee, as where the grant is to A and his heirs so long as the land is used for school purposes, ${ }^{109}$ the grantor retains a contingent right of reverter. The policy of the law, however, set certain limits upon the restrictions which may be placed upon the powers of the grantee in fee. For example, it will not permit any restraint upon his power of alienation..$^{110}$

Recalling that tenure is but the name applied to certain groups of

${ }^{105}$ Coke, Littleton, *I43 b; 2 Blackstone, Commentaries, *42; Edwards, op. cit. 223; Cuthbert v. Kuhn (I838, Pa.) 3 Whart. 357, 365.

${ }^{100}$ Coke, Littleton, * ${ }_{I 43}$ b; Watkins, Conveyancing, ${ }^{I 75}$; Vas Rensselaer $v$. Hays, supra note 44 .

${ }^{107}$ Despite the rule at common law that a right [power] of entry for condition broken though descendible, was not alienable (Coke, Littleton, $*_{214}$ a) some courts seem to have regarded the right of entry reserved for non-payment of a rent charge as so essential an incident of the rent as to pass to the grantee of the rent. See I Tiffany, op. cit. supra note 104 , sec. 86 (b) at p. 3r4; Kenege v. Elliot ( $1840, \mathrm{~Pa}$ ) 9 Watts, 258; Roberts v. Ristine (1856, Pa.) 2 Phila. Rep. 62; Van Rensselaer $v$. Slingerland (1863) 26 N. Y. 580 ; Van Rensselaer v. Read (1863) $26 \mathrm{~N} . \mathrm{Y} .558$. But even if the right of entry was not assignable at common law, it was made assignable in New York by Laws, 1846 , ch. 274, sec. 3. See Van Rerusselaer $v$. Slingerland, supra at p. 585 .

${ }^{103}$ See Coke, Littleton, *20r a; Farley v. Craig (I830) II N. J. L. 262.

${ }^{100}$ Halpin v. School District No. 9 (1923, Mich.) 194 N. W. 1005; Board of Education v. Littrell (1917) $173 \mathrm{Ky} .78$, 190 S. W. 465.

${ }^{10}$ See De Peyster v. Michael (1852) 6 N. Y. 467; Parmalee v. Morris (1922) 218 Mich. 625, I88 N. W. 330. 
numerous and important though varying legal relations which society permitted from time to time to exist between grantor and grantee of lands in fee, we can see that the relations mentioned above as permitted after the statute Quia Emptores, and still permitted, while wholly consistent with the provisions of that statute are none the less "tenurial" in their nature. Like tenures in case of grants of estates less than fees simple, they do not come within the purview of that statute.

It is not suggested that the relation existing between grantor and grantee of a lawfully restricted conveyance in fee should be called. "tenure," 111 for that would but add to the existing confusion of thought. But recognition of the fact that such relation is similar to "tenure" removes much difficulty. Thus Professor Gray, in his admirable treatise on Perpetuities ${ }^{112}$ reflecting the statements made by divers learned judges, says that rights (powers) of entry for condition broken reserved on grants in fee are not reversionary rights, nor dependent on tenure. Hence they are valid and enforceable, though it is manifest they may be exercised at a remote date. But contingent rights (possibilities) of reverter after the termination of an estate in fee granted on special limitation are reversionary rights he thinks, and therefore, being dependent upon "tenure," cannot exist after the statute Quia Emptores. ${ }^{113}$ Thus he would contend that if A, tenant in fee, granted a messuage to $B$ and his heirs, but upon the condition that if said messuage should ever be used for any purpose other than as a parsonage ${ }^{114}$ for the Methodist Episcopal Church, A or his heirs might re-enter and retake the same, the reserved interest of $A$ is perfectly valid, and $B$ 's title unmarketable. But if the grant should be to $B$ and his heirs so long as the messuage should be used as a parsonage and no longer, $A$ would reserve no valid interest and B's title would be absolute. However, the courts have refused to make any such distinction, ${ }^{115}$ and hold the interest reserved valid in either case, and with good reason as the analysis already suggested shows. In each case $A$, the grantor, has reserved an interest in the land conveyed, a contingent power of entry

111 It is interesting to note, however, that when a grantor in the Province of Massachusetts Bay wished to negative the incidents of tenure, he was accustomed to grant "'a good, perfect, and absolute estate of inheritance in Fee Simple, without any manner of condition, reversion, or limitation whatever.' Suffolk Deeds, passim." Bond, op. cit. I5, note.

${ }^{112}$ Sec. 30.

113 Ibid. sec. 31 .

"' See In re Estate of Douglass (I9I3) 94 Neb. 280, I43 N. W. 299, in which the right of reverter was fully recognized.

iix Professor Powell summarizes his review of the authorities as follows: "Thus it would appear that in eighteen of the United States, determinable fees do exist and are recognized and dealt with as possible legal interests in realty. Many of these states have reached this result since the first edition of Gray's Rule against Perpetuities presented his reasons why such estates no.longer existed. Every court which has adverted to his position in this matter, has done so only to dissent therefrom." Op. cit. supra note 13, at p. 231 . 
in one case and a contingent right of possession in the other. $\mathrm{He}$ might, of course, by an absolute conveyance, have extinguished all of his legal relations with respect to the land, but the intention of the parties was that he should reserve a power of entry in one case, a right of possession in the other, and the words of the deed are apt to effectuate this intent. This intent will be given effect unless prohibited by some positive enactment, or contrary to some settled rule of public policy. The statute Quia Emptores, as shown above, has no application. ${ }^{116}$ The only question then remaining is whether such reservations are opposed to the principle upon which rests the rule against perpetuities, and should on that account be held void. The courts in the United States, at least, have held, however questionably, that neither of these reservations is obnoxious to the rule, ${ }^{112}$ and granting the soundness of such holding, there remains no reason why both interests should not be given effect.

This conception of tenure as merely a label for certain groups of legal relations removes the occasion for the embarrassment felt by the American courts, especially those of New York, in dealing with "perpetual leases," that is, conveyances in fee in which the grantor has reserved an annual rent forever, with power to levy distress, and the power of re-entry upon non-payment of rent. In Pennsylvania the courts have experienced comparatively little difficulty in working out the mutual rights of the parties to deeds creating "ground rents," as they are called, on the common law theory of tenure held to be in continued existence there..18 In South Carolina it is probable that the same use might be made of the ancient statute which still operates to keep socage tenure alive in that state if ground rents were in vogue, which appears not to be the case. But in New York the courts have been hard put to it to arrive at sensible results with all tenures abolished and the statute Quia Emptores still in good working order; so hard put to it, that it has been said that the courts have pronounced the law in favor of one party and judgment in favor of the other. ${ }^{119}$ And such, on superficial consideration, would seem to be the case, for in Kavanaugh v. Cohoes Power \& Light Corp., ${ }^{120}$ the most recent case on the subject, Hinman, J., says: "The abolition of feudal tenures and their incidents effectually put an end to the strict relation of landlord and tenant which could only arise in connection with some feudal tenure.

${ }^{110}$ Professor Powell seems to approve the contention of Challis in Determinable Fees (1887) 3 LAw Q. REv. 403, reprinted in Challis, Real Property (3d ed. I9II) App'x. IV, 437, that the statute Quia Emptores has no application to determinable fees since it is limited to lands "tenerdis in feodo simpliciter tantum," and determinable fees are not so holden. Even though this contention is not wholly convincing, Mr. Zane is a bit extreme in declaring it "wholly inept." See Determinable Fees in American Jurisdictions (1904) I7 HARv. L. REv. 299, note 9.

${ }^{113}$ See Gray, op. cit. secs. 299-313; Powell, op. cit. supra note I3, at p. 232.

${ }^{118}$ See supra note 8r.

${ }^{113}$ See Kavanaugh v. Cohoes Power \& Light Corp., supra note 5, at p. 6I8.

${ }^{120}$ Supra note 5 , at p. 623 . 
Thereafter by convention of the parties a relationship could be constituted resembling in many essential particulars that existing under a feudal tenure, which we, in these times, invariably refer to as the conventional relation of landlord and tenant. Fundamentally, the contrast between the strict relation and the conventional relation is sharp. The change from the one to the other, however, has come about so gradually and so naturally that it is confusing to attempt to trace it." He then proceeds to hold in effect that while feudally there could be no tenure between grantor and grantee in fee, yet conventionally the grantee under a deed of "perpetual lease" did hold"121 of the grantor and could not claim that his possession or user was adverse.

In accord with what has been stated above, this means that while the statute of 1830 following that of 1787 abolishing tenures has destroyed the old legal relations that in feudal times were created by feoffment through implication from existing social and political conditions, there is no reason why parties to a conveyance in fee should not by express agreement make any reasonable distribution of the grantor's bundle of legal relations that may suit their needs and desires, always provided that it is not repugnant to the law of the land. As a matter of fact the Van Rensselaer leases in fee did cause distress and disturbance, resulting in a constitutional provision limiting leases of agricultural lands to twelve years..$^{122}$ Similar limitations are found in other states. ${ }^{123}$ It is quite possible that experience may demonstrate that conveyances in fee with reservation of perpetual rent, especially when power of re-entry for non-payment is reserved, are contrary to the public welfare as imposing unmanageable and hurtful incumbrances upon the ownership of land. In that case they may be restricted or even prohibited, but as yet there is little reason to expect early statutory interference. ${ }^{124}$

12 The court quotes with approval the statement made in Hosford $v$. Ballard (I868) 39 N. Y. I47, I5I, that "one who holds land by any kind of title, whether for years, or for life, or in fee, is a tenant, and he of whom land is held subject to the rendering or payment of rent or service is landlord."

223 "No lease or grant of agricultural land for a longer period than twelve years, hereafter made, in which shall be reserved any rent or service of any kind, shall be valid." Constitution, 1846, art. I, sec. 14; retained in Constitution, 1894, as art. I, sec. I3.

${ }^{22}$ See Mich. Constitution, I850, art. XVIII, sec. I2 (twelve years); Minn. Constitution, I857, art. I, sec. I5 (twenty-one years); Iowa Constitution, 1857 art. I, sec. 24 (twenty years); Wis. Constitution, I848, art. I, sec. I4 (fifteen years); Calif. Civ. Code, Ig09, sec. 717 (fifteen years).

${ }^{12}$ In Pennsylvania the creation of irredeemable ground rents has been prohibited. See Act of $1850, \mathrm{~Pa}$. Sts. I920, sec. II, at p. 807 ; Act of $1885, \mathrm{~Pa}$. Sts. I920, sec. II, at p. 808. In Maryland any tenant holding under a lease for more than fifteen years is given the privilege of "redeeming" the rent, that is, of buying in the reversion after a period designated. See Code Pub. Gen. Laws, I904, art. 2I, secs. 88,89 . This privilege is given in the interest of the public and not merely for the benefit of the tenant. Hence it cannot be waived or evaded. Stewart v. Gorter (1889) 7o Md. 244, I6 Atl. 644. In Alabama no lease for a longer period than ninety-nine years is valid. Code, I907, sec. 3418, as amended by Acts, I9II, No. 4I. 
On the contrary, in the great states of Pennsylvania ${ }^{125}$ and Maryland ${ }^{126}$ such conveyances are numerous and looked upon with favor by the courts; and in many other states ${ }^{127}$ they have been before the courts without exciting any judicial indignation. In any event we may safely say that whatever name we may apply to the relationship between the grantor and his rent-paying grantee, the grantor's retained interest in the land is fully recognized, and need no longer be frightened by the immaterial ghost of the statute Quia Emptores.

By way of summary answer to the initial question, Is there tenure in the United States? we are justified in making the following statements:

I. At all periods of the history of the Anglo-American law of real property, it has been assumed that the absolute ownership of all lands was originally in the Sovereign, whether called "crown" or "state"; that is, the Sovereign possessed the largest bundle of rights, powers, privileges and immunities, unburdened by any duties, liabilities or disabilities, that can conceivably be enjoyed with respect to lands.

2. At no time has the sovereign in making grants to subjects parted with the whole bundle of "sticks" (to use the crude but striking figure now current in the classroom) which make up his absolute ownership,

${ }^{2123}$ See Cadwalader, op. cit. 64.

${ }^{206}$ See Banks v. Haskie (1876) 45 Md. 207, 218. In Maryland ground rents usually take the form of leases for ninety-nine years, renewable forever. While the interest of the lessee has been held not to be a fee (Allender v. Sussan [1870] $33 \mathrm{Md}$. II), but rather of the nature of personalty (Posner v. Bayless [1882] 59 Md. 56), yet most of the incidents of this peculiar estate are those of realty. See Crowe v. Wilson (1886) $65 \mathrm{Md}$. 479, 482, 5 Atl. 427, 428; Camp v. Boyd (I913) 229 U. S. 530, 33 Sup. Ct. 785.

${ }^{127}$ See Cronk v. Shoup (I92I) 70 Colo. 7I, I97 Pac. 756; Brown v. Pierce (I916) 29 Del. 326, 99 At1. 530; Succession of Canonge (1846) I La. Ann. 209, 2II; Gale v. Edwards (I864) 52 Me. 363; Stark v. Mansfield (Igor) I78 Mass. 76,59 N. E. 643 ; Rochester Lodge v. Grahom (1896) 65 Minn. 457, 68 N. W. 79; Alexander v. Warrance (1852) I7 Mo. 228; Smith \& Sargent v. American Car Sprinkler Co. (I9I6) 78 N. H. I52, 97 Atl. 872; Farley v. Craig, supra note I08; McCammon v. Cooper (1904) 69 Ohio St. 366, 69 N. E. 658; Shaw v. Partridge (1845) 17 Vt. 626; Norfolk v. Perry Co. (1908) 108 Va. 28, 6I S. E. 867; Leonard v. Henderson (I873, Va.) 23 Gratt. 33I. See also Scott v. Lunt (I833, U. S.) 7 Pet. 596, in which George Washington was grantor; United States $v$. St. John's Gas Co. (Ig09) 5 Porto Rico Fed. I73.

In Georgia it appears that conveyances in fee have been made with reservation of rent to be paid annually forever, or until an agreed lump sum should be paid. It is held that both grantor and grantee have estates in the land but the grantor's estate is only reserved to secure the payment of the purchase money or rent. Hence when the grantor had entered under the power reserved for non-payment of rent, and sold the land, the purchaser got good title (Swoll v. Oliver [1878] 6r $\mathrm{Ga}$ 248); but the grantor so forfeiting the estate of the delinquent tenant must account to him for the excess of the money received on resale above the amount due from the first purchaser. Laurence v. Savannah (I883) 71 Ga. 392; Wells v. Savannah (189I) 87 Ga. 397, I3 S. E. 442. The grantee in such a deed is solely liable for taxes assessed upon the land. Perick v. Atkinson (I9r3) I39 G2. 649, 77 S. E. I055. 
but in ancient "feudal" times he retained more numerous and more important sticks of this bundle than he does in modern "allodial" times. The relationship between sovereign and occupant of land has long been called tenure, and may well enough continue to bear that label in the United States as well as in England, even though the sovereign's bundle of retained legal relations is greatly shrunken.

3. "Allodial tenure" is a proper enough phrase, despite much criticism. There is no such thing as absolute ownership of land by the subject or citizen. Allodial tenure is the robust feudal tenure grown sadly emaciated with all its teeth fallen out. The same thing may be said of the socage tenure declared to exist in South Carolina.

4. Feudal tenure between two subjects was justified only when it accompanied the exercise of limited governmental powers. The statute Quia Emptores recognized this fact, and in substituting the new grantee to the place of the grantor in the old feudal relationship, made the creation of new feudal tenures between subjects impossible. This statute did not, however, prevent the grantor in fee from retaining such legal relations with respect to the land as might be agreed upon and properly reserved in the deed of conveyance, always provided they were not prohibited by statute or by any settled rule of common law, such as the rule against perpetuities or that against restraints upon alienation.

5. Hence the grantor in fee may still reserve a power of entry upon breach of condition, or he may reserve a right of possession contingent upon the termination of a fee upon special limitation (possibility of reverter) just as a mortgagor may reserve a power of defeasance. These, like feoffments before I29o, are transfers of restricted ownership, and the relationship existing between grantor and grantee might have been called tenure, but such has not been the custom. The statute Quia Emptores has no application to them.

6. Unless forbidden by special enactment, perpetual leases may be validly made, that is, grants in fee reserving perpetual rent, with power of distress and of entry upon non-payment of rent creating two estates in the same land, each descendible and assignable, without the aid of any tenure other than that which the parties have set up by their agreement. 